\title{
One Century of English Translations of Ján Kollár (1832-1931)
}

\author{
Marián Andričík (Košice)
}

\begin{abstract}
This survey attempts to summarise English translations of poems written or collected by a Slovak poet Ján Kollár that appeared during one century both in Great Britain and in the United States, from Bowring's seminal anthology in 1832 to Underwood's selection of Slavic Poetry in 1931. They prove that Ján Kollár is the most frequently translated poet of both the Slovak National Revival and the history of Slovak poetry. In addition to collecting the most relevant sources (anthologies and surveys of literature), the paper analyses and evaluates particular translations, some in mutual comparison, to show methods and procedures of respective translators. Even though the poetry of Ján Kollár became a part of many anthologies, a separate English edition with the selection of his poems is still missing.
\end{abstract}

\section{Key words}

translation; poetry; anthology; rhythmic substitution; semantic shift; semantic density; sonet; metaphor

\begin{abstract}
Abstrakt
Storočie anglických prekladov Jána Kollára (1832-1931)

Tento prehl'ad sa usiluje zosumarizovat' anglické preklady básní, ktoré napísal alebo zozbieral Ján Kollár a vyšli v priebehu storočia vo Vel'kej Británii a v USA - od prelomovej Bowringovej antológie z roku 1832 až po Underwoodovej výber zo slovanskej poézie v roku 1831. Dokazujú, že Ján Kollár je najčastejšie prekladaným básnikom tak slovenského národného obrodenia, ako aj celých dejín slovenskej poézie. Okrem zozbierania najrelevantnejších zdrojov (antológií a prehladov litreratúry) štúdia analyzuje a hodnotí konkrétne preklady, niektoré vo vzájomnom porovnaní, a naznačuje metódy a postupy jednotlivých prekladatelov. Hoci sa poézia Jána Kollára stala súčastou mnohých antológií, samostatný výber z jeho tvorby v angličtine stále chýba.
\end{abstract}

\section{Klúčové slová}

preklad; poézia; antológia; rytmická substitúcia; sémantický posun; sémantická hustota; sonet; metafora

This study is an outcome of the VEGA research project No. 1/0407/17 Slovak Poetry in English Translations. 
In the quest for English translations of Slovak poetry, which go back to the 1830s, one cannot but expect to find some great names of literary history either in anthologies, surveys of literature, or separate selections. Ján Kollár (1793-1852), a leading figure of the Slovak National Revival, undoubtedly ranks among them. Born in Mošovce, Slovakia, but writing in Czech, having dismissed Štúr's codification of standard Slovak, calling it "the language of coachmen", Kollár is settled both in the history of the Czech and the Slovak literature and his poetry found its way into no less than fifteen anthologies of poetry in English, which makes him the most frequently translated Slovak poet of all times. This presence mostly leans on his most famous poetic composition The Daughter of Sláva (Slavy dcera, 1824) but some editors also drew from his first book of verse The Poems of Ján Kollár (Básně Jána Kollára, 1821) for some shorter poems, or even from his work as a collector of folk songs, published in two volumes of National Songs (Národnie zpievanky, 1934/5).

\section{John Bowring: Cheskian Anthology, Being a History of the Poetical Literature in Bohemia (1832)}

The first anthology where we can find Kollár's poems in English is Cheskian Anthology, Being a History of the Poetical Literature in Bohemia, edited and translated by an English polyglot and translator John Bowring (1792-1872), and published in London in 1832. Bowring, anglicising his first name to "John Kollár", introduces him as "a bohemian minister at Pesth, in Hungary"1, appreciating his talent: "I am much mistaken if he will not be deemed worthy of praise and admiration. The affecting tenderness, the melancholy sweetness with which he dwells on the fate of his country, and the eager enthusiasm with which he rears up the dreams of her future power and happiness appear full of the finest materials of thought and expression". Bowring who has not "scrupled to translate poetry pretty largely from his works", translated 34 sonnets from the first edition of The Daughter of Sláva in 1824 plus 7 more sonnets that were included in its second, enlarged edition in 1832. Besides, the flyleaf of the book contains two lines from The Daughter of Sláva in Czech and English: Pravou vlast jen v srdci nosime / tuto nelze biti ani krásti. (Our heart - our country's casket and defense - / Our country, none shall steal - none tear it thence.)

Forty-one sonnets can be considered a fairly good number to introduce a previously unknown poet to foreign readers, even though it makes less than one-tenth of the number of 615 sonnets included in the second edition of The Daughter of Sláva. The number is decent also concerning sonnet as a high poetic form that calls for an exceptionally skilled translator. Prosodically, Kollár's sonnets can be characterised by three basic features:

1 BOWRING, John: Cheskian Anthology, Being a History of the Poetical Literature in Bohemia. London: Rowland Hunter, St. Paul's Churchyard, 1832, p. 195-196.

2 Ibidem.

3 Ibidem, p. 195. 
1. Trochaic metre (making a five-feet trochaic line). Kollár decided to use it under the influence of Josef Jungmann who employed it in his translation of Milton's Paradise Lost, and also under the influence of German poets. As Krausová states, later he was criticised for this decision by Czech poets Jaroslav Vrchlický and Otokar Fischer ${ }^{4}$.

2. Italian (Petrarchan) form of sonnet, based on two quatrains and two tercets. In the first edition of The Daughter of Sláva, the source for Bowring's translation, Kollár used the rhyme scheme ABBA but the structure of tercets is varied with the most frequent rhyme scheme having been CDE CDE (in 121 out of 154 sonnets). Six sonnets end with the scheme EE.

3. Alternation of feminine and masculine line endings; it was Ján Kollár who canonised this kind of alternation in Slovak poetry.

All these features are very important in translation to English since they cannot be systematically preserved because of objective differences between the two languages. It means that we can imagine an English sonnet of trochaic metre and Italian form including alternation of feminine and masculine line endings, however, it cannot work as a principle on a bigger scale.

John Bowring was surely well aware of this obstacle and lesser rhyme possibilities of English in comparison with Czech, that is why he used Kollár's model of quadruple rhymes in the quatrains only in ten sonnets. On the other hand, no less than 26 out of 41 sonnets end with Shakespearian heroic couplet while Kollár used it only in six out of 154 sonnets. We cannot blame Bowring for his exclusive rhythmical substitution of iambic metre for trochaic one, which is understandable because of its strong tradition in English poetry from Sir Thomas Wyatt, Edmund Spenser, William Shakespeare, John Milton, William Wordsworth, John Keats to Elizabeth Barrett Browning. Similarly, we cannot see as a shortcoming of Bowring's translation his decision not to preserve the alternation of feminine and masculine line endings that is unexceptionally applied in the original. Since feminine line endings are quite infrequent in English, their application - even in quadruple rhymes - would inevitably have led to rhythmical levelling ${ }^{5}$ and repetition. Such sonnets are rare in the English tradition - let us recall Shakespeare's $20^{\text {th }}$ sonnet with its a unique standing within the whole collection due to its sole usage of feminine endings, which even formally corresponds with a central topic of the sonnet a woman's beauty (A woman's face with nature's own hand painted... $)^{6}$.

Bowring, who well knew these prosodic obstacles of translation from a Slavic language, made good room to minimise the occurrence of undesirable semantic shifts. Semantically, Bowring's translation oscillates between maximum faithfulness and excessive looseness. It can well be seen in the translation of the opening sonnet of his selection:

4 KRAUSOVÁ, Nora: Vývin slovenského sonetu. Bratislava: Tatran, 1976, p. 40.

5 The term coined by Anton Popovič in POPOVIČ, Anton (ed.): Originál-preklad: interpretačná terminológia. Bratislava: Tatran, 1983.

6 Shakespeare in VENDLER, Helen: The Art of Shakespeare's Sonnets. Cambridge: Harvard University Press, 1997, p. 127. 


\section{9. sonet}

Neni to zem ani nebe zcela, co se z tváre Jeji vyskytá, svatost je to v kráse zavitá, duše božská v outlé cloně těla; hned mře láskou, hned zas jakby chtěla vzhưru létnout, city zamítá, do ruk běží, ai, v blesk rozlitá světy hvězd Ji plynou vuikol čela:

Ba si, tušim, všudypř́tomnosti ode bohů samých pưjčila, ant' mi veždy $v$ očich, $v$ obraznosti; o, rci prèdce, družko rozmilá, jsi-li trupel, až si trudu spořim, či-li anjel, at’ se tobě kořím.

\section{Sonnet 9}

Not earthly charms, - nor heavenly are alone,

In thine incomparable grace exprest;

'Tis holiness in human beauty drest,

Time's shade around immortal brightness thrown:

Now chain'd to fleeting love - and now upflown

From the faint passions of a time-bound breast,

To the unclouded sunshine of the blest;

From dust and darkness - to the lightning throne.

There stars roll o'er there, - from whose radiant light

Thou didst receive the rays thou scatter'st round,

While flashing like a vision of the sight;

Say wert thou moulded from the clayey ground,

That I may love thee? - if thou art divine -

An angel - I will worship at thy shrine.

We can see the difference already in the way the speaker approaches his beloved Mina: while Kollár uses the third person, Bowring addresses her directly, thus strengthening the contact relation and increasing the emotional value of the statement. While the third line ('Tis holiness in human beauty drest) is almost the exact copy of the original (svatost je to v kráse zavitá), the very next one departs from it, replacing the indicated dualism of the soul and the body, present in European culture from ancient times, by the differently set dualism of the shade of time and the immortality of brightness. He partly compensates for this shift in the second quatrain in the motif of time-bound breast. 
What can be viewed as disputable in relation to the original is the first tercet where Bowring transfers the image of stars surrounding Mina's forehead from the second quatrain, weakening gradation at the same time. Despite an effective alliteration (dust and darkness), the motif of omnipresence that Kollár establishes in the first tercet is not developed any longer, instead, Bowring develops the image of stars: here we can see quite a departure from the original while the semantics of the second tercet is more or less preserved. It is questionable whether such shift can be justified by structural specifics of the English type of sonnet in comparison with the Italian one. In our opinion, different distribution is not necessarily the reason for excessive semantic shifts. A closer look at Kollár's sonnet reveals the phenomenon Helen Vendler spotted as a typical feature of Shakespeare's sonnets and called it "a couplet tie" - the final heroic couplet usually contains an expression already used in previous quatrains that "ties" these parts and semantically agglutinates the whole poem. We can find a similar phenomenon in Kollár's sonnets: in this one, every part of the poem contains an expression related to spirituality, thus strengthening his admiring attitude to Mina: 1. božská (divine), 2. vzhưru (up), 3. bohů (Gods), 4. anjel (angel). From this point of view, the above-mentioned semantic deviation in the translation disturbs this symmetry.

Despite some disputable solutions, Bowring's translations from The Daughter of Sláva made a good service to Kollár and for the first time introduced Slovak poetry in English speaking countries.

\section{Albert Henry Wratislaw: Lyra Czecho-slovanská. Bohemian Poems, Ancient and Modern (1849)}

In the mid-19 $9^{\text {th }}$ century, there came another anthology with Kollár's poems in Great Britain. Albert Henry Wratislaw (1822-1892) was an English Slavist of Czech descent and a priest at Christs's College in Cambridge, where also John Milton studied in the $17^{\text {th }}$ century. His anthology of Bohemian poems includes one Kollár's poem - Change of Taste (Proměna chuti), published in his first book of verse Poems of Ján Kollár (Básně Jana Kollára) in 1821. An interesting fact is that even though an enlarged edition of The Daughter of Sláva was published in that time, Wratislaw did not include any extract of it in his anthology. Instead, he opted for a poem Miroslav Vojtech assigns to poems "perhaps most closely connected with previous poetic tradition by their character", their anacreontian and pastoral themes following earlier line of poetry promoted by Juraj Palkovič and Bohuslav Tablic ${ }^{7}$.

7 VOJTECH, Miloslav: Syntéza poézie, vedy a mýtu v diele Jána Kollára. In: Štúdie k jubileu Jána Kollára. Historia Nova 5. Ed. Podolan, Peter. Bratislava: Filozofická fakulta Univerzity Komenského, 2012, p. 16. 


\section{Proměna chuti}

(Zpěvanka)

Di̛no! jak jest nestálé

lidské prirození,

jak se často na odpor

věk a serdce mění.

Malí, co jest malého,

viobec rádi maji,

o co, když jsou velicí,

velmi málo dbají.

Se mnou však je naopak,

an byv maličický,

holuby jsem miloval,

nyni holubicky.

\section{Change of Taste}

'Tis wonderul how changeable

The race of man is found,

How frequently with alt'ring age,

the heart too turneth around!

When little, they with little things

Most delighted are,

For which, when they are bigger grown,

they very little care.

In me though it inverted is,

This change of youthful flames,

Tom-pigeons once I us'd to love,

But now I love the dames*.

* Holuby tom-pigeons - holubice, dame-pigeons - holubičky, little dame pigeons, also a term of endearment.

Semantically, the translation itself does not differ from the original much, and Wratislaw, in a similar way to Bowring, resorts to an expected rhythmical substitution. The only disputable point of his translation can be found at its end where the ambiguous term "holubičky" proved too hard nut to crack for the translator. Therefore, he added 
a footnote explaining the ambiguousness of the expression. Thus, the effect of the translated poem becomes dependent on this footnote while in the original it lies in the point. What deserves to be mentioned, too, is a motif of flames in the last stanza, probably brought by rhyme ("dames"), that seems to be an attempt to metaphorically replace the double diminutive "maličičký", unattainable in English.

Whatever praiseworthy Wratislaw's effort was, certainly, his anthology cannot be taken as a reliable source of information about Kollár's work for English speaking readers. Although further selections were still to come, as for the bulk of his poetry translated into English, none of them ever beat Bowring and his anthology.

\section{Talvj: Historical View of the Languages and Literature of the Slavic Nations With a Sketch of Their Popular Poetry (1850)}

As Clarence A. Manning (1893-1972) points out in the Preface to his Anthology of Czechoslovak Poetry (1929), the work of German-American linguist and translator Talvj (acronym from her full name Therese Albertine Luise von Jakob Robinson, 1797-1870) Historical View of the Languages and Literature of the Slavic Nations With a Sketch of Their Popular Poetry "was one of the first serious attempts in the English-speaking world to produce

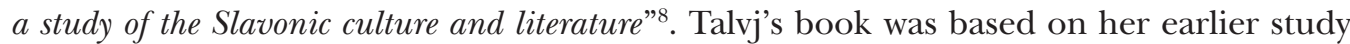
published in the journal The Biblical Repository in April and June 1834.

The reason we mention this book in our study is that the part four of this voluminous, more than 400-page publication, called Sketch of the Popular Poetry of the Slavic Nations, brings two Slovak folk songs probably coming from Kollár's collections of Slovak folk songs National Songs ${ }^{9}$ (Národnie zpievanky, 1834, 1835) and Wordly Songs of Slovak People in Hungary (Písně světské lidu slovenského v Uhřích, 1823, 1827) ${ }^{10}$. The first one is a ballad The Mother's Curse from Volume Two of National Songs, there to be found as Mother Seeks for her Girl (Mati diovča sháňa), the second one is a short song Sun and Moon ${ }^{11}$, included in Volume One of Wordly Songs of Slovak People in Hungary under the title If Only My Beloved (Keby mi milý muoj).

As for the ballad The Mother's Curse, Talvj mentions its occurrence also in the region of Silesia under the title Kuhländchen but finds the Slovak version more original. Compared to Kollár's unstrophical syllabic variation of trochaic metrical tendency (close to an alexandrine), the translation consists of iambic quatrains with some lines varied either by the addition of extra syllables or rhythmically. A remarkable fact is that save

8 MANNING, C. A. (ed.): An Anthology of Czechoslovak Poetry. With the assistance of Anna V. Capek and Alois B. Koukol. New York: Columbia University Press, 1929, p. v.

9 The translator may have used a different source of this ballad since in comparison with Kollár's version, the translation contains several changes (initial and some other lines are missing). We can find similar rendering of this theme also in other folk ballads like Fiddlers Went through the Forest (Išli hudci horou).

10 Kollár, unlike Šafárik, is not credited in the first edition.

11 Clarence A. Manning took this translation over to his Anthology of Czechoslovak Poetry. New York: Columbia University Press, 1929. 
for minor exceptions, the translation tries to apply feminine endings in odd lines, which could be interpreted as a slight tendency to foreignisation. The only major semantic shift (if we do not take into account missing lines in comparison with Kollár's version) is a motif of brandreth at the beginning as the reason why the maiden could not draw water from the well, that was replaced for the one of thick ice (She there could draw no water / So thick the frost it lay).

The second folk song Sun and Moon, an English version of a short, eight-line song If Only My Beloved (Keby mi milý muoj) that uses a six-syllable verse with alternate rhyme, is a sigh of a maiden upon an unrealised date with her beloved one, poetically compared to the meeting of the sun and the moon. The translation varies a six- and five-syllable verse, alternating iambic and trochaic lines, and slightly raises the emotional character of the song by adding an interjection "Ah!" at the beginning of the first lines of both stanzas.

A contemporary point of view may show untypical word order in both songs: There came one day two lads / two minstrels young hey were - The Mother's Curse; Ah! If but this evening / Would come my lover sweet - Sun and Moon. However, such inversions are not exceptional in English folk ballads. Wolfgang G. Müller claims: "Inversion is particularly conspicuous in sentences which introduce a new element of the action" 12 , therefore it cannot be considered disturbing in these translations.

\section{Percy Paul Selver: An Anthology of Modern Bohemian Poetry (1912)}

A significant contribution to the knowledge of the Slovak poetry in the English speaking world goes to Percy Paul Selver (1880-1970); his translations were published in four anthologies, while he compiled three of them himself.

Born in London to a Jewish family, Selver was a teacher for seven years and later contributed to an avant-garde literary magazine New Age. After the establishment of Czechoslovakia, he worked at the Embassy of Czechoslovakia in London and was an advisor for the exile government. When he finished his diplomatic career in 1954, he was a member of the editorial board of The Poetry Review.

In 1912 Selver published his first selection from Slavic Literatures An Anthology of Modern Bohemian Poetry. Ezra Pound appreciated in his review in the magazine Poetry, however, he criticised it for its translation: "This is a good anthology of modern Bohemian poetry, accurately translated into bad and sometimes even ridiculous English." 13

The only poem written by a Slovak poet that Selver included in his anthology is The Daughter of Sláva, Prelude (Slávy dcera, Předzpěv), published in English for the first time. At the same time, this poem goes beyond Selver's ambition to present Bohemian poetry of "recent date". In his Preface, Selver explains: "Kollár's elegy was written as early as in 1824 but was included here because of its importance as a landmark in the revival of Bohemian

12 MÜLLER, Wolfgang G.: Syntactic Features of the Folk Ballad. AAA: Arbeiten aus Anglistik und Amerikanistik, Vol. 6, 1981, No. 2, p. 234.

13 POUND, Ezra: Bohemian Poetry. Poetry, Vol. 2, 1912, No. 1 (november), p. 57. 
poetry, and as a general expression of Slavonic temperament." ${ }^{14}$ The English translation is an attempt at an accentual-syllabic substitution for the original quantitative elegiac couplet. It combines mainly dactylic and trochaic metre with the occasional use of iambic one: out of 112 lines of Prelude, 89 begin in dactyl, 17 in trochee, and 6 in iamb. Selver's translation method can be characterised as slightly archaising. He often uses shortened forms with an apostrophe: 'fore my eyes; o'erflowing; 'twas the cradle; 'tis the tomb; 'gainst the treacherous time; ne'er has an enemy yet; 'tis but the same; Goth tho' he be; but 'tis in vain; how to sail o'er the sea; nature that ne'er can be changed; o'er his loves' bones; is o'erthrown, obsolete expressions: that stands there yonder; O ye years; thine hands; for this what recompense hast thou?; yonder the stranger's foot; Nature alone doth remain; Coldly in sooth, or sometimes changes in word order, probably in an effort to get as close to the original semantically as possible. This brought several breaches of fixed English word order which could have had an unnatural and artificial effect on readers - as Ezra Pounds confirms in his reaction. Here are some examples:

Však času ten horši je člověk, jenž berlu železnou / v těchto krajich na tvou, Slávie, šiji chopil. Ah, but worse than the time, is the man, who a sceptre of iron, / Slavia, on thy neck, here in these lands has imposed;

Sám svobody kdo hoden, svobodu zná vážiti každou,

Only of liberty worthy is he who can liberty value.

ne kdo divé chválil přikladem ordě pokoj.

Not who to untamed hordes peace by example extolled.

nalevo zrak bystře otáč́m,

to the left I searchingly turn me,

než mé darmo oko v Slávii Slávu hledá.

that my Eye Sláva in Slávia seeks.

Sometimes it is the word order of the original itself that causes semantic shifts, leading the translator astray:

po světě neštastnou války pochodni nosil:

Into the hapless world carried the torch of dissent;

Here we can see that the expression neštastnou (hapless in translation), referring to the torch in the original, was linked with the world, thus producing a negative shift. On top of that, the choice of the word dissent, clearly for rhythmical reasons, instead of the original války ("war”), results in expressional weakening. However, in another place

14 SELVER, Percy Paul (ed.): An Anthology of Modern Bohemian Poetry. London: Henry J. Drane, 1912 , p. 3. 
Selver strengthens the expression by making it more explicit - where Kollár laments to heavens, Selver directly calls for vengeance:

A kdo se loupeže té, volajici vzhưru, dopustil?

Who has committed this theft that cries for vengeance to heaven?

On the other hand, Selver chose a more liberal approach in lines with genitive metaphors, obviously evading them in his translation:

Rozšklubaný hnusné zpotvořenosti věnec.

Torn is thy garland in twain, hatefully robbed of its form.

osluněným rozptyl mráčky myšlének okem.

Scatter with eye like the sun thoughts that arose in a cloud.

In general, we could characterise Selver's method in this translation of Prelude (others were to come) as predominantly preserving. A certain price paid for it was unnatural diction and some minor semantic shifts.

\section{Otto Kotouč: Songs of the Slav (Translations from the Czecho-Slovak) (1919)}

This small selection, compiled and translated by an American politician from Nebraska and a son of Czech parents Otto Kotouč (1885-1973), was published in 1919 in Boston and included only five poets. One of them was Ján Kollár whose two sonnets from the third canto of The Daughter of Sláva (1862 edition) open the whole book. In a short Preface, Kollár is introduced as the Slovak poet "known as the poet of Pan-Slavism" 15.

In the first sonnet, an elegy about the disunity of the Slavs, Kotouč slightly weakens the expression by translating the attribute rozkydani as divided, neglecting its other connotations: "set against each other", "strife-torn". Elsewhere, however, the expression is strengthened: in the first line of the second stanza, obviously for metrical reasons, he adds the phrase in scorn to a neutral statement about calling the Slavs a dove-like nation. At the same time, he changes the patient from "you" to "we". In the fourth line, this time probably for the sake of rhyme, he uses an inappropriate attribute reviled for a trait typical of doves the speaker wishes the Slavs to apply. From the structural point of view, the translator preserves an Italian type of sonnet with two quatrains and two tercets. The substitution of iamb for trochee and abandoning quadruple rhymes are justifiable. Kollár's principle of alternating feminine and masculine rhymes is indicated only by one feminine rhyme in the first tercet, not to be repeated in the second one.

15 KOTOUČ, Otto: Songs of the Slav (Translations from the Czecho-Slovak). Boston: The Poet Lore Company, The Gorham Press, 1919, p. 4. 
The second sonnet, a visionary poem introducing the poet's idea of the recovery of the Slavs and their expansion in Europe, begins with two rhetorical questions. As in the first sonnet, the patient is changed, too, but reversely: Kotouč renders Kollár's call Co $z$ nás Slavu bude o sto rokü? (What will become of us Slavs in hundred years?) in a more neutral way: What will become of Slavs in hundred years? Slightly more explicit is the first line of the second quatrain: where Kollár mentions Germans in general and their relation to the speech of the Slavs, the translator speaks about German henchmen. Aside from this, there are no serious semantic deviations from the original. We could also appreciate the fact that Kotouč decided not to preserve frequent inversions, which makes the English version sound smoother and more natural. Various rhyme schemes in quatrains (ABAB in the first, $\mathrm{ABBA}$ in the second) may be a little disturbing concerning a specific poetic form - sonnet. Kollár's departure from trochaic metre towards iambic one in the first two lines of the second quatrain finds its parallel in translation. Contrarily, in the first line of the first tercet, Kotouč uses transaccentuation to change its beginning to trochaic.

Small as it may be by its size, Kotouč's anthology deserves credit for being the first one to introduce Slovak poetry to readers in The United States.

\section{Percy Paul Selver: Anthology of Modern Slavonic Literature in Prose and Verse (1919)}

Seven years after his first anthology of modern Bohemian poetry, Paul Selver came with an anthology of wider scope, aimed at Slavic literature and bringing his translation of Russian, Ukrainian, Polish, Czech, Serbo-Croatian and Slovenian authors. To a certain extent, it is surprising that he did not resort to some examples of Slovak literature, not excepting Prelude to Kollár's The Daughter of Sláva that was a part of his first anthology in 1912. Selver just mentions Kollár as "one of the poets of Czech revival"16, quoting four lines from Prelude in his translation:

Where have ye wandered, dear nation of Slavs that formerly dwelt here,

Now Pomerania's springs, now drinking deep of the Saale,

Peaceful stock of the Sorbs, and Obotritian offspring,

Where are the Wilzen, and where, grandsons of Uker, are ye?

What should be pointed out in this context, is the question of Slavic languages where Selver mentions a Slovak linguist Samo Czambel (1856 - 1909) who "insists on a distinct Slovak race (of Southern Slav origin) with a distinct Slovak language (again not altogether justly)" ${ }^{17}$. Perhaps Selver was not convinced of the existence of the separate Slovak language at that time, however, later he probably revised his opinion by publishing two more anthologies in 1929 and 1946 with a wider representation of Slovak poetry.

16 SELVER, Percy Paul (ed.): Anthology of Modern Slavonic Literature in Prose and Verse. London: Kegan Paul, Trench, Trubner \& Co. Ltd., 1919, p. ix.

17 Ibidem, p. x. 


\section{František Chudoba: A Short Survey of Czech Literature (1924)}

Czech literary historian, translator, and professor of English philology at Masaryk University in Brno František Chudoba (1878-1941) was a lecturer of Czechoslovak language and literature at King's College in London in the 1920s. His selection from Czech and Slovak literature is not a typical anthology since it is based on Chudoba's courses and lectures, bringing a concise outline of the history of literature from Hussite wars to political independence within Czechoslovakia. Stemming from the idea of a united Czechoslovak nation, Chudoba considers Czechs and Slovaks ethnographically and politically to be one nation with one language that exists "in a double literary form: in the Czech literary dialect and a Slovak literary dialect", the difference between them being "a slight one"18.

All translations of both Czech and Slovak authors are credited to Paul Selver. The selection presents two Slovak poets - Ján Kollár with Prelude to The Daughter of Sláva and Ivan Krasko with two poems.

As the following examples show, apart from the fact that this edition contains only 80 lines compared with all 112 lines of 1912 version (quoted here first) of Prelude, we can find minor revisions in Selver's new rendering: reduction of short forms, more natural word order and an option for other synonyms:

Here lies the country, alas! 'fore my eyes that in tears are o'erflowing,

Here lies the country, alas! before my tear-laden glances,

'Gainst the treacherous time holding its own till to-day.

Holding its own against treacherous time, till to-day.

Ah, but worse than the time,

Ah, but more evil than time,

Only of liberty worthy is he who can liberty value,

Worthy of freedom is only he who values all freedom,

Countenance seemingly Slav sadly the hearing deceives.

Countenance seemingly Slav sadly the hearing belies.

18 CHUDOBA, František: A Short Survey of Czech Literature. London: Kegan Paul, Trench, Trubner \& Co. Ltd., 1924, p. 2. 


\section{Clarence Augustus Manning: An Anthology of Czechoslovak Poetry (1929)}

The editor of another anthology containing Slovak poetry that was released in New York in 1929, was an American Slavist and professor at Columbia University Clarence Augustus Manning (1893-1972).

In his Preface, Manning does not claim his book to be "a general anthology of Czechoslovak poetry" and sets his aim more humbly, as a "collection of Czechoslovak poetry as translated in the New World" ${ }^{19}$. However, it has an important place in the history of English translations of Slovak poetry because in spite of its title evoking the idea of Czechoslovakism, it publishes Slovak poetry (including Kollár) in a separate section for the first time.

Regardless of two folk songs, one taken over from the above-mentioned book by Therese A. Robinson (Talvj) Historical View of the Languages and Literature of the Slavic Nations With a Sketch of Their Popular Poetry (1850) and the other translated by Ivan Kramoris, the short selection of Slovak poetry begins with two sonnets by Ján Kollár borrowed from Kotouč's anthology and slightly revised. As for the first sonnet, Kotouč just added one syllable at the end of rhyming lines in the first tercet ( $O$ Slavs, thou race of many fragments torn!; But waste and dry the circling currents mourn), thus eliminating feminine endings and uniting the sonnet rhythmically into five-feet iambic lines. Changes in four lines of the second sonnet are rather grammatical or stylistic than prosodic (older version quoted first):

What will become of Slavs in hundred years?

What will the Slavs be in a hundred years?

And even spoken be by lips of foe.

And even spoken be by every foe.

Sciences shall likewise Slav channels see;

The sciences shall Slav exponents see;

I shall then rise up from my grave again.

Let me but rise up from my grave again.

19 MANNING, C. A. (ed.): An Anthology of Czechoslovak Poetry. With the assistance of Anna V. Capek and Alois B. Koukol. New York: Columbia University Press, 1929, p. v. 


\section{Paul Selver: An Anthology of Czechoslovak Literature (1929)}

In the same year when Manning published his anthology in New York, there appeared another Paul Selver's volume with poems of Slovak authors in London ${ }^{20}$. Dedicated to a Russian symbolist Konstantin Balmont, the book, introducing the history of Czech and Slovak literature, brings samples of seven Slovak poets from classicism (Kollár) to modernism (Krasko, Rázus). Slovak authors, with much humbler representation in comparison with their Czech counterparts, are marked with an asterisk in the contents, with the only exception - Ján Kollár. Again, Selver published his Prelude to The Daughter of Sláva in the version that came out in Chudoba's anthology in 1924 (with 82 instead of 80 lines). The only modification comes in the title: The Daughter of Sláva, Prelude was changed to The Prologue to The Daughter of Sláva. Selver also commented on it in his Introduction, calling it "stately rhetoric", and assigns it slightly lesser emotional appeal in comparison with the Croatian poet Peter Petarović and his ode To Slavdom written in 1863. "Kollár's somewhat illusory and unpractical Pan-Slavonic ideas," Selver claims, "gave rise later to the so-called, Illyrian movement"'21.

\section{Edna Worthley Underwood: The Slav Anthology: Russian, Polish, Bohemian, Serbian, Croatian (1931)}

Quite shortly after Manning's anthology, another selection of Slavic poetry was published in the United States, this time in Portland. The Slav Anthology was edited by a poet, novelist, and translator Edna Worthley Underwood (1873-1961).

In her Foreword, the editor writes: "Many of the verses of this Slav Anthology were published more than thirty years ago, in magazines, and in newspapers" ${ }^{2}$. It is clear that in this anthology, where most attention goes to Russian authors, Kollár is presented in the section of Bohemian literature. Underwood mentions Kollár together with Čelakovský among a school of poets "who, with a gift of genius, molded Bohemian poetry into an art that placed in on a level with the work of Western Europe". His epic, The Daughter of the Slava, she states, "was effective, not only upon Bohemian peoples, but upon writers throughout Russia, Poland"23. Underwood selected 64 lines from the Prelude and supplemented it with two sonnets from The Daughter of Slava (sonnet 257 from the first canto and sonnet 326 from the second canto).

Underwood, who had had previous experience with translating Slavic poetry (Miczkiewicz's Sonnets from the Crimea among them), proved to be a sensitive reader with a good

20 In 1946, Selver published an anthology A Century of Czech and Slovak Poetry, not included in this survey, with another and different translation of the Prelude to The Daughter of Sláva.

21 SELVER, Percy Paul, ed.: An Anthology of Czechoslovak Literature. London: Kegan Paul, Trench, Trubner \& Co. Ltd., 1929, p. 5-6.

22 UNDERWOOD, Edna Worthley: The Slav Anthology: Russian, Polish, Bohemian, Serbian, Croatian. Portland: The Mosher Press, 1931, unpaged.

23 Ibidem, p. 248. 
sense of fluency and natural expression in poetry. Nevertheless, she was not able to avoid some shifts in meaning. Also, it is a pity that she published only one half of the Prelude, having left some substantial parts from it out. This omission is particularly disputable in those parts where it interferes in the elegiac distich. Leaving one of the two lines that belong together out means an intervention into the prosodic unity and, certainly, the simplification of the meaning. Here are two examples:

A kdo se loupeže té, volajici vzhưru, dopustil?
kdo zhanobil v jednom národu lidstvo celé?

Who is the one who has done this, the crime perpetrated, the bloody?

Ten porobu slušnou, bud' Goth, bud' Skýta, zasloužil,

ne kdo divé chválil př́kladem ordě pokoj.

Be he Scythian or Goth, does not change it, he it is, who earns chains.

Like previous translations of the Prelude by Selver, Underwood's version is also an accentual-syllabic substitution of the original, sometimes disrupted by the above-mentioned omissions of lines or by their iambic beginnings. Occasionally, obviously for the reason of prosody and semantic density, she adds elements not present in the original. In the second line Once 't was our cradle, our pride, now 't is the grave of the Slav, the added expression our pride does not interfere with the central meaning of the poem but it steps in the opposition cradle (once) - grave (now). Further mentionable semantic shifts are mostly caused by an effort to achieve an effective alliteration: fight self, forging fate; plotting and planning for death; for greed or for gain - in all of these, the acoustic effect is compensated by the departure from meaning. What is also objectionable is the translator's solution to use the synecdoche the oak forest for the original dubisko ("the big oak-tree"), thus dispersing the original symbolic meaning of a robust tree the Slavic nations can cling to in an image of a forest. For comparison, in his 1912 and 1929 anthologies, Selver used the mighty old oak, later changed into great oak-tree in his anthology The Century of Czech and Slovak Poetry, published in 1946. Contrary to Selver, who - perhaps for being a European - did not hesitate to use the names Vistula and Baltic in all three of his translations, Underwood probably found some toponyms in the Prelude unfamiliar to her prospective readers, therefore she replaced them with more general terms:

Od Labe zrádného $k$ rovinám až Visly nevěrné, od Dunaje k heltným Baltu celého pěnám:

From the banks of the Elb to the treacherous waters to eastward, From the Danube likewise to far seas of white-flying foam: 
Sometimes her translation makes more explicit what was hidden in a metaphor. The following example shows as though Underwood underrated her readers in making the idea of subjugating the landlord clear. This is especially visible in comparison with Selver who attempted to preserve the image:

Tak tu domu vlastni podroben pán, chytře mu vlezlý
soused ovil těžký smutně o herdlo řetěz.

That was the fate of the Slav Land, when the people themselves were made slaves there,

Slyly the neighbor, the traitor, slipped up and bound it in chains.

So in his own domain the master is serf, while its neighbour

Slyly crept in and his neck woefully bound with a chain.

Two sonnets from The Daughter of the Slava (No. 326 and 257 in the 1832 edition) included in this anthology appear to be a sort of compromise between an Italian and an English type of sonnet, preserving two quatrains with the rhyme scheme ABBA, but adding one more quatrain and a heroic couplet. The metre is an iambic pentameter and all rhymes in both sonnets are solely masculine. This along with natural diction makes the sonnets read smoothly and from this point of view, there is almost nothing we could reproach the translator for. Maybe only the decision to use quadruple rhymes that resulted in repeating the same or similar words in rhyme position: One - One (in the first sonnet) and awhile - while (in the second sonnet). More shifts influencing the overall expression of the poems affect the use of tropes. Underwood does not stick to the meaning of the original strictly and her approach is rather free. We can see it in the first sonnet where she omits a pope from the first quatrain and replaces Kollár's synecdoche The one who once sang Iliad with his very name Homer. Again, at the beginning of the second quatrain, she changes an image of stars compared to fleece for which the speaker would not change his love to Fleece that Jason won, thus explaining what the original just indicates. Moreover, phrases like palaces that blaze above the plain, or pearls that show not any stain do not correspond to the original semantically and are put there for the sake of rhyme.

In the second sonnet, the translator used the metonymy Bohemia's Forest instead of the toponym Šumava, which can be justified with relation to prospective readers - unlike the replacement of the key image of the sonnet, the one of the rivers in the speaker's

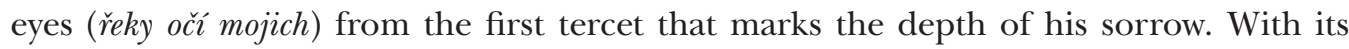
more positive connotations, the attribute splendour in the English equivalent splendour of my tears departs from the original. This departure goes on in the last tercet, though, because instead of using the agrarian metaphor in the speaker's plea to the sun sheave all your splendors in one harvesting, in the original the speaker asks the sun to hurry first to his love and not only to tell her his message, as is indicated in the translation, but to kiss her lips, eyes, and face: 
když tam prìjděs, rozkaž, aby zári

blesky tvé $k$ Ni pervé spichali

zlíbati Ji rtiky, oči, tvárír.

And when at last the space of day is run,

Sheave all your splendors in one harvesting,

And tell het 't is my message that you bring.

Despite all their failings, translations of Kollár's poetry made by Edna Worthley Underwood are worthy of our appreciation for her decision to include his poems to her anthology of Slavic poetry.

\section{Conclusion}

We may argue whether presentations in ten English or American anthologies within the span of one century is or is not sufficient for such significant poet of Slovak and Czech literature like Ján Kollár. One thing is certain - his poetic mastership, strong message and the impact of his poetry in the Slavic world must have appealed to the editors of the anthologies, which makes him the most frequently translated Slovak poet (even though writing in Czech) in history. As our analysis shows, translations of his verse vary in extent and quality, however, they should be praised for bringing this great poet of our history to English-speaking readers. Much in his field was mainly done by a pioneer in translating Czech and Slovak poetry, John Bowring, whose anthology brought a considerable amount of Kollár's poetry, never beaten up to the present time. Although literary history saw further translations of Kollár from the 1940s to 1970s in various English, American, or even Australian anthologies, a separate volume of his poetry is still missing. This can pose a challenge for translators into English to confirm that the message of his poems got by no means stuck in the $19^{\text {th }}$ century and can also address contemporary readers.

\section{Literature}

BOWRING, John: Cheskian Anthology, Being a History of the Poetical Literature in Bohemia. London: Rowland Hunter, St. Paul's Churchyard, 1832.

CHUDOBA, František: A Short Survey of Czech Literature. London: Kegan Paul, Trench, Trubner \& Co. Ltd., 1924.

KOLLÁR, Ján: Básně Jána Kollára. Praha: Jozefa Fetterlová z Wildenbrunu a arcybiskupská knihtiskárna, 1821.

KOLLÁR, Ján: Sláwy dcera we třech zpewjch od Jana Kollára. Budín: Králowská universitická tiskárna, 1824. 
KOLLÁR, Ján: Sláwy dcera. Lyricko-epická báseñ w peti zpewjch. Pešt: Tiskem Trattnera a Károliho, 1832.

KOLLÁR, Ján: Národnie zpievanky čili Písně světské Slovákio v Uhřich, jak pospolitého lidu, tak i vyššich staviu, sebrané od mnohých, v pořádek uvedené, vysvètlením opatrenené a vydané od Jána Kollára. Dí pervý. Vydáni hodně rozmnožené i pervé dva tištěné svazečky v sobě obsahujicí. Budín, 1834; Díl druhý. Budín, 1835.

KOLLÁR, Ján: Národné spievanky. I. diel. Bratislava: Slovenské vydavatel'stvo krásnej literatúry, 1953.

KOLLÁR, Ján: Národné spievanky. II. diel. Bratislava: Slovenské vydavatel’stvo krásnej literatúry, 1953.

KOLLÁR, Ján - ŠAFÁRIK, Pavel Jozef: Piesne svetské l'udu slovenského v Uhorsku. Bratislava: Tatran, 1988.

KOTOUČ, Otto: Songs of the Slav (Translations from the Czecho-Slovak). Boston: The Poet Lore Company, The Gorham Press, 1919.

KRAUSOVÁ, Nora: Vývin slovenského sonetu. Bratislava: Tatran, 1976.

MANNING, C. A. (ed.): An Anthology of Czechoslovak Poetry. With the assistance of Anna V. Capek and Alois B. Koukol. New York: Columbia University Press, 1929.

MÜLLER, Wolfgang G.: Syntactic Features of the Folk Ballad. AAA: Arbeiten aus Anglistik und Amerikanistik, Vol. 6, 1981, No. 2, pp. 227-240.

NOYES, G. R.: An Anthology of Czechoslovak Poetry by Clarence A. Manning. The Slavonic and East European Review, Vol. 8, 1929, No. 23 (december), p. 461.

Písně světského lidu v Uhřich. Sebrané a vydané od Pavla Jozefa Šafařika, Jana Blahoslava a jiných. Svazek první. Pešt', 1823; Svazek druhý. Pešt, 1827.

POPOVIČ, Anton (ed.): Originál - preklad: interpretačná terminológia. Bratislava: Tatran, 1983.

POUND, Ezra: Bohemian Poetry. Poetry, Vol. 2, 1912, No. 1, (november), pp. 57-59.

SELVER, Percy Paul (ed.): An Anthology of Modern Bohemian Poetry. London: Henry J. Drane, 1912.

SELVER, Percy Paul (ed.): Anthology of Modern Slavonic Literature in Prose and Verse. London: Kegan Paul, Trench, Trubner \& Co. Ltd., 1919.

SELVER, Percy Paul (ed.): An Anthology of Czechoslovak Literature. London: Kegan Paul, Trench, Trubner \& Co. Ltd., 1929.

TALVJ: Historical View of the Languages and Literature of the Slavic Nations With a Sketch of Their Popular Poetry. New York: George P. Putnam, 1850.

UNDERWOOD, Edna Worthley: The Slav Anthology: Russian, Polish, Bohemian, Serbian, Croatian. Portland: The Mosher Press, 1931.

VENDLER, Helen: The Art of Shakespeare's Sonnets. Cambridge: Harvard University Press, 1997.

VOJTECH, Miloslav: Syntéza poézie, vedy a mýtu v diele Jána Kollára. In: Štúdie k jubileu Jána Kollára. Historia Nova 5. Ed. Podolan, Peter. Bratislava: Filozofická fakulta Univerzity Komenského, 2012, p. 12-34.

WRATISLAW, Albert Henry: Lyra Czecho-slovanská. Bohemian Poems, Ancient and Modern. London: John W. Parker, 1849. 
prof. PhDr. Marián Andričík, PhD.

Department of Slovak Studies, Slavonic Philologies and Communication

Faculty of Arts, Pavol Jozef Šafárik University in Košice

Moyzesova 9, 04001 Košice, SK

marian.andricik@upjs.sk to relevant rights. 
